2. Guha, S. C., Fonseca, V., Fink, I. M. (2009). Hyperhomocysteinemia and thrombosis. Seminars in thrombosis and hemostasis, 3(25) [in English].

3. Selhub, J., Fidalgo, T., Margues, D., Tamagnini, G. (2010). Hyperhomocysteinemia and methylenetetrahydrofolate reductase (MTHFR) mutation in patients with stroke. 16th Congress of thrombosis and haemostasis. Porto [in English].
4. Rosen, R. (2007). Genetic predisposition to hyperhomocysteinemia: methylenetetrahydrofolate deficiecy of Thrombosis and Hemostasis, 1(78), 523-527 [in English].

5. Boers, G. H. (2007). Hyperhomocysteinemia as a risk factor for arterial and venous disease: a review of evidence and relevance. Thrombosis and Hemostasis, 1(78), 520-523 [in English].

Svyatoslav Linnikov, teaching assistant of Department of General Disciplines and Clinical Medicine, The State institution "South Ukrainian National Pedagogical University named after K. D Ushynsky" 26, Staroportofrankivska Str., Odesa, Ukraine.

\title{
HYPERHOMOCYSTEINEMIA AS THE PATHOGENETIC FACTOR IN OBSTETRICAL COMPLICATIONS
}

The study of the influence of various levels of the hyperhomocysteinemia with mutation in methylenetetrahydrofolate reductase (MTHFR) on the system of the hemostasis was carried out. 84 patients were examined with various obstetrical pathology in the anamnesis. The genetic form of the hyperhomocysteinemia with various degrees of severity has been revealed in 21 (25\%) patients. At the stage of planning of pregnancy and in the I-st trimester the thrombophilia manifestations were revealed: increasing the activity thrombocytes, the quantity of markers of thrombophilia D-dimer, TAT, F1+2. Thrombophilia augmented with terms of preeclampsia and the degree of severity of the hyperhomocysteinemia. The offered pathogenetic algorithm of treatment of thrombophilia state of patients using the low-molecular weight heparin (clexane), a folic acid, vitamin B6, B12 antioxidants has given the significant positive effect. It is necessary to carry out the studies of the hemostasis on latent thrombophilia and to carry out, if necessary, the antitromboembolitic therapy to establish the ethiopathogenetics of obstetrical complications. It will enable to exclude the further perinatal losses.

Keywords: hyperhomocysteinemia, methylenetetrahydrofolate reductase, thrombophilia, a folic acid, lowmolecular weight heparin (clexane).

Подано до редакиії 12.05.2020

УДК 616.7009.70036.12

DOI: https://doi.org/10.24195/2414-4665-2020-1-8

Анатолій Чустрак,
кандидат педагогічних наук, дочент,
приват-професор кафедри гімнастики та спортивних єдиноборств,
Артемій Кізірян,
відмінник народної освіти Украӥни,
Едвард Кізірян,
студент периого курсу медичного відділення,

Державний заклад «Південноукраӥнський національний педагогічний університет імені К. Д. Уиинського», вул. Старопортофранківська, 26, м. Одеса, Украӥна

\section{ОСОБЛИВОСТІ ВПЛИВУ РЕВЕРСИВНОЇ ДІЇ УДАРНО-ХВИЛЬОВИХ ТРЕНАЖЕРІВ НА ФІЗІОЛОГІЧНИЙ ТА ФІЗИЧНИЙ СТАН УЧНІВ}

3 метою підвищення інтересу старшокласників до фізичної культури та збільшення їх рухової активності були організовані емпіричні дослідження реверсивної дї створених ударно-хвильових тренажерів на фізичний стан старшокласників (n-85) у порівнянні з іншими фізичними засобами. Дослідження проводились у трьох класах на уроках фізкультури в підготовчій частині, тричі на тиждень по 15 хвилин, протягом шести місяців. Один клас був контрольним, у другому переважали спортивні ігри, у третьому - загально-розвиваючі вправи з тренажерами ударно-хвильової дії, названими «Ударник». На початку та в кінці експерименту визначали у школярів 2 антропометричні показники, 4 фізіологічні показники і 8 показників фізичних даних - та як на ијі 
показники впливають вправи ударно-хвильової дії у порівнянні з іншими засобами фізичної підготовки через півроку. До педагогічного експерименту майже всі фізичні якості старшокласників були на низькому рівні. Після шестимісячного експерименту достовірно покращились майже всі показники школярів експериментальних класів. Вони показали добрі та задовільні результати, як фізичного розвитку, так і основних фізичних якостей за виключенням спритності, згідно державних нормативів. Використання на уроках фізичної культури тренажерів ударно-хвильової дії «Ударник» підвищує інтерес старшокласників до фізичної культури. Такі вправи знижують масу тіла, підвищують функиіональні адаптивні можливості сериево-судинної системи, добре тренують гнучкість, ивидкість, силову витривалість, швидкісно-силові та силові якості школярів. Результати дослідження можуть бути корисними для тренерів та вчителів фізичної культури загальноосвітніх шкіл.

Ключові слова: старшокласники, вправи ударно-хвильової дї, фізичні якості, фізична підготовленість.

\section{блеми}

Вступ та сучасний стан досліджуваної про-

Проблема розвитку фізичних якостей в умовах шкільної освіти та сімейному вихованні в сучасних умовах, у зв'язку з різким зниженням рухової активності є достатньо актуальною. В науково-педагогічній літературі накопичений значний арсенал різних технологій, систем, вправ, як загального характеру, так і спеціалізованого в залежності від виду шкільної або спортивної діяльності, орієнтованих на розвиток в учнів фізичних якостей (Булатова, Литвин, 2004; Носко, Єрмаков, Гаркуша, 2010; Lubysheva, 2001; Чустрак, 2015 та інші). При цьому не рідко пропонують різне спортивне обладнання, пристрої, тренажери та інше. Використання їх як в комплексі, так і окремо сприяє розвитку різних фізичних якостей дітей шкільного віку (Петров, Солодка, 2010; Laputin, 1990; Topchiieva, 2012; Watson, 2001; та інші). Методика тренування ударних вправ в східних єдиноборствах, відомих ще тисячі років тому, в основному базуються на принципах ударно-хвильової дії. Давно відома позитивна дія різних вправ з використанням струшування та м'язової вібрації: різновиди ходьби, біг підтюпцем, різноманітні опорні, безопорні та із скакалкою стрибки, танцювальні вправи. Метання дротика, спиca, диска, гранати; вправи з холодною зброєю: шпагою, рапірою, шаблею, мечем; удари в боксі, карате та інших єдиноборствах; спортивні ігри: волейбол, ручний м'яч, теніс та інші не обходяться без струшування. В 1927 році була створена система оздоровлення Кацудзо Ніші. В 1936 році вона була надрукована англійською мовою. В 2004 році «Система здоров'я Кацудзо Ніші» вийшла російською мовою в Санкт Петербурзі (Кацудзо Ниши, 2004). Сам Кацудзо Ніші визнавав, що ця система - не його винахід. Він вивчив та перевірив на практиці багато методів та систем зцілення людей, серед яких були давньогрецька, давньоєгипетська практики, методи тибетської, китайської, філіппінської медицини, йога, а також дослідження відомих йому спеціалістів в області біоенергетики та оздоровлення, в тому числі вправи для підсилення та розширення капілярної сітки кровоносних судин людини за допомогою струшування. 31995 року рекламується «Тренажер Агашина», 3 яким можна виконувати вправи ударно-хвильової дії. Так звані «волнарі» були реалізовані Ф. К. Агашиним (а. с. на винахід СРСР 387720 і 423829) (Агашин, 1975; Агашин, 2006). Надалі два напрямки розділилися: автоколивальними волнарями продовжував займатися Агашин Ф. К. у варіанті біомеханічних верстатів, що реалізують ме- тод вторинних ударів, а також спільно з М. Ф. Агашиним у варіанті «гантелей динамічних», що забезпечують автономний «хвильовий» режим тренування. Вібраційні методи і засоби біомеханічної підготовки, крім Ф. К. Агашина, розробляє велика група фахівців Самарського аерокосмічного університету (Самарський національний дослідницький університет ім. академіка С. П. Корольова) під керівництвом проф. В. С. Савельєва. Згідно твердження академіка М. М. Амосова, для досягнення відповідного ефекту буде потрібно всього 3-5 хвилин замість 30-50 хвилин за звичайною методикою. Маються дані про те, що вправи 3 «гантелею динамічною» нормалізують показники артеріального тиску і частоту серцевих скорочень (ЧСС), підвищують споживання кисню і покращують гемодинаміку (Фролов та інші, 1989). Але ці тренажери та віброгантелі досить дорогі та виготовити їх самостійно неможливо. Досить привести рекламні ціни: «Тренажер Агашина» - 182,82 грн у Москві; «віброгантелі»: «Shake weight» - 275 грн, «Supretto shake» - 449 грн, віброгантелі для фітнеса від 1984 до 2325 грн! В основному вони рекомендуються як звичайні гантелі $60 \%$ і тільки $30 \%$ для легкого силового струшування однією рукою. Для оздоровлення людей була також рекомендована так звана «віброгімнастика», автора М. Гогулан (2002), яка сама себе вилікувала за системою Кацудзо Ніші. Рекламуються також більше ніж 40 способів лікування за допомогою електричних та електронних приладів ударно-хвильової дії в неврології, ортопедії і травматології та косметології, які теж досить дорогі. У зв'язку з цим, у своїй роботі ми зосередили свої зусилля на створенні такого пристрою у вигляді тренажерного знаряддя для використання його в різних умовах фізичного виховання школярів. При цьому ми припустили, що такий пристрій повинен бути: по-перше, простим у використанні; по-друге, доступним у придбанні чи власному виготовленні; по-третє, мати вплив на системоутврюючу основу функціонування м'язової системи. Головна суть всіх пристосувань ударно-хвильової дії - це створення мікровібрації та динамічної інерції м'язової та серцево-судинної систем. Оскільки останні є індикатором і ресурсним джерелом ефективного функціонування м'язової системи та умовою для більш ефективного розвитку різних фізичних якостей. Для вирішення поставленої мети були поставлені наступні завдання:

\section{Мета та завдання}

1. Розробити тренажерний пристрій ударнохвильової дії для використання його в різних умовах 
фізичного виховання школярів.

2. Провести апробацію тренажера в умовах школи за показниками зміни фізичного розвитку та фізичної підготовленості старшокласників в педагогічному експерименті за допомогою вправ 3 тренажерами ударно-хвильової дії.

Внаслідок попередніх досліджень (Чустрак, Кизирян, Шавриева, 2018: 101-105), нами був розроблений в остаточному вигляді тренажерний пристрій у двох варіантах, який умовно назвали «Ударник». Перший варіант - для дівчат: пластиковий циліндр об'ємом 500мл має висоту 21 см та наповнений на $2 / 3$ водою, всередині якого два металевих стержні діаметром 15мм і довжиною 11 та $15 \mathrm{~cm}$. Вагу тренажера до 500г регулювали дрібною галькою. Другий варіант для хлопців: циліндр об'ємом 580мл має висоту $23 \mathrm{~cm}$ та наповнений на $2 / 3$ водою, всередині якого два металеві стержні діаметром 15мм та довжиною 15 та $18 \mathrm{~cm}$. Вагу регулювали до 1000 г дрібною галькою. Циліндри можна замінити відповідними пластиковими пляшками 3 такою ж висотою та об'ємом. Таким чином дівчата в кожній руці тримали пластикові тренажери по 500г, а хлопці - по 1000г, в основному, у вертикальному положенні при ходьбі, бігу, присіданнях, стрибках на місці та інших різноманітних загально-розвиваючих вправах. Реверсивні дії тренажерів під час руху та на місці виконувались 3 максимальною амплітудою та обов'язковим акцентованим струшуванням в кінцевих положеннях, що викликало додаткову внутрішню вібрацію всередині тренажерів, яка передавалась на м'язи і серцево-судинну систему та, за нашими припущеннями, створювала сприятливі умови для фізичного розвитку. Наприклад, у вихідному положенні (В.П.) - стійка ноги нарізно правою вперед, тренажери внизу. На рахунок: 1 - тренажери вгору; 2 - струшування; 3 - нахил вперед, тренажери максимально назад, струшування; 4 - В.П; В.П. стійка ноги нарізно, тренажери внизу. 1 - нахил вправо, правою - тренажер вгору, лівою - тренажер за спину. 2 - струшування двома тренажерами; 3-4 - теж 3 нахилом вліво. Другий момент: вправи підсилювалися пружинячими нахилами. Використовували також образні вправи: «Ножиці» - багаторазові хресні рухи в горизонтальному та вертикальному положеннях тренажерів; «Бокс» - різкі рухи одночасно однією рукою вперед, іншою - назад, тренажери в горизонтальному положенні, перпендикулярно до тулуба. Третій момент: при ритмічному колективному виконанні виникало щось подібне на барабанний дріб або музичний супровід. Це викликало позитивні емоції у дітей і вони $з$ задоволенням виконували вправи, що підсилювало ефективність виконання вправ. Філатов А. Т. (1979) розглядав такі форми дії людей один на одного в колективі, як «вправи 3 посмішкою на обличчі», що «формують оптимальний психологічний клімат у спортивних командах». Наведені ці та інші комплекси вправ 3 тренажерами «Ударник» підлягали апробації на уроках фізкультури протягом шести місяців.

\section{Організація та методики дослідження}

В дослідженні прийняли участь старшокласники 10-х класів віком від 15,5 до 16,5 років, дівчата (n 35) та хлопці $(\mathrm{n}-52)$. Визначали антропометричні показники: довжину та масу тіла школярів; фізіологічні: життєву ємність легенів (ЖЕЛ), артеріальний тиск крові (АТ), частоту серцевих скорочень (ЧСС), насичення (сатурацію) гемоглобіну артеріальної крові киснем $\left(\mathrm{SpO}^{2}\right)$ та фізичні дані за допомогою педагогічних тестів: гнучкість, швидкісно-силові якості: стрибки через скакалку за 1 хвилину та стрибки в довжину 3 місця; силову витривалість м'язів живота: піднімання із положення лежачи в положення сидячи за 1 хв.; швидкість - біг $60 \mathrm{~m}$; спритність - човниковий біг (4x9 м); силу кисті та станову силу школярів. Протягом шести місяців тричі на тиждень в трьох класах, які достовірно не відрізнялись між собою за показниками фізичного розвитку та фізичної підготовленості, проводили уроки з переважним використанням різних фізичних засобів: 10-а, К клас - був контрольним, де проводились звичайні уроки за державною програмою; 10-б, Е1 клас - переважна спрямованість на спортивні ігри (волейбол, баскетбол та ручний м'яч, протягом 15 хв. після підготовчої частини уроку); 10в, Е2 клас - переважна спрямованість на загальнорозвиваючі вправи 3 тренажерами «Ударник», створюючи реверсивні дії, протягом 15 хвилин після підготовчої частини уроку.

\section{Результати дослідження}

До експерименту за середніми показниками довжина тіла юнаків 10-х класів виявилась нижчою від середніх даних оціночних таблиць - (від М-1б до М$2 \boldsymbol{\sigma})-166,5$ см, а показники довжини тіла дівчат виявились середніми - (від М+1б до М-1б) - 165,6 см, хоча достовірної статистичної різниці між показниками довжини тіла у хлопців та дівчат не виявлено. Маса тіла як у юнаків - 63,9 кг, так і у дівчат - 55,4 кг за даними оціночних таблиць виявилась вищою середніх показників (від $\mathrm{M}+1 \boldsymbol{\sigma}$ до $\mathrm{M}+2 \boldsymbol{\sigma})$. Маса тіла хлопців була достовірно більшою від маси дівчат в середньому на 8,5 кг $(\mathrm{P}<0,01)$. Життєва ємність легенів, яка відображає можливість регуляторної здатності організму керувати зовнішнім диханням, відповідала віковим стандартам як у хлопців - 3,4 л, так і у дівчат 2,6 л. Загально прийнято, що відхилення на 10-15\% відповідає нормі, (Гербут, 2015). Середні показники ЖЕЛ хлопців були на 0,8 л більшими ніж у дівчат, $(\mathrm{P}<0,05)$. За загальною думкою лікарів, в $16-20$ років АТ: $100 / 70$ - 120/80 мм рт. ст. вважається нормальним. В експериментальних дослідженнях (М. В. Йолтухівський та інші, 2017: 31) було виявлено, що через гипокінезію, яка дуже поширена останнім часом серед школярів, в «16 років $50 \%$ хлопців та $78 \%$ дівчат мають низький та нижче середнього рівень функціонального стану ССС». «Достовірне зниження адаптаційних можливостей системи кровообігу виявлено в юнаків у кінці пубертатного періоду (16 років), що свідчить про відносну функціональну незрілість їх адаптаційних систем». Ця тенденція простежується також у наших дослідженнях. При середніх показниках АТ у юнаків 118/68,8 мм. рт. ст. і варіаціях від 113/64 до 122/71,5 та при середніх показниках АТ у дівчат 111/75,3 мм. рт. ст. і варіаціях від 104/66 до 121/80 мм. рт. ст., у більшості школярів спостерігається зниження показників, як систолічного, так і діастолічного тиску. Середні показники ЧСС у юнаків 
виявились дещо вищими - 79,3 уд./хв., порівняно 3 такими у дівчат - 76,2 уд/хв., 3 варіаціями у хлопців від 77 до 83 уд./хв. та у дівчат - від 75 до 77,8 уд./хв. $\mathrm{B}$ нормі $\mathrm{SpO}_{2}$ становить 95-98 \% (у людей, старших за 70 років - 94-98 \%). В наших дослідженнях середні показники $\mathrm{SpO}^{2}$ у юнаків - 96,2\% при варіаціях від 94 до $98 \%$ та у дівчат - 95,8\% при варіаціях від 95,6 до
96\%, (Таблиця 1). Як засвідчило дослідження старшокласників до експерименту, гнучкість у юнаків за середніми показниками $+9,2$ см при розбіжності: $+(6,2-$ 11,6 см) знаходилась на низькому рівні (2 бали, за Державними тестами населення України), а у дівчат - 12,7 см при розбіжності $(12,3$ - 13 см) - на середньому рівні (3 бали, за Державними тестами).

Середні антропометричні та фізіологічні показники иколярів 10 класів до педагогічного

Таблиця 1 експерименту

\begin{tabular}{|l|c|c|c|c|c|c|c|}
\hline Стать & $\mathrm{n}$ & \multicolumn{2}{|c|}{ Антропометричні } & \multicolumn{4}{|c|}{ Фізіологічні показники } \\
\cline { 3 - 8 } & $\begin{array}{c}\text { Довжина } \\
\text { тіла (см) }\end{array}$ & Маса (кг) & $\begin{array}{c}\text { ЖСЛ } \\
\text { (л) }\end{array}$ & $\begin{array}{c}\text { АТ } \\
\text { (мм. рт. ст.) }\end{array}$ & $\begin{array}{c}\text { ЧСС } \\
(\text { уд/хв.) }\end{array}$ & $\begin{array}{c}\mathrm{SpO}^{2} \\
(\%)\end{array}$ \\
\hline Юнаки & 35 & $166,5 \pm 0,67$ & $63,9 \pm 0,57$ & $3,4 \pm 0,32$ & $118 / 68,8 \pm 1,3 / 2,4$ & $79,3 \pm 0,7$ & $96,2 \pm 0,3$ \\
\hline Дівчата & 52 & $165,6 \pm 0,53$ & $55,4 \pm 0,62$ & $2,6 \pm 0,27$ & $111 / 75 \pm 2,4 / 1,5$ & $76,2 \pm 1,3$ & $95,8 \pm 1,2$ \\
\hline
\end{tabular}

Стрибки через скакалку за 1 хв. у юнаків - 96,5 разів при розбіжності: (81 - 111,8 разів). Дівчата показали дещо кращі середні результати стрибків через скакалку - 102,2 раз при варіаціях (90-122 рази). Досить низькі показники стрибка у довжину з місця показали юнаки - 176,6 см при варіації (155 -200 см), що за Державними тестами - нижче 2 балів. Дівчата теж були кращими у стрибках з місця - 171,8 см при варіаціях (157,3-200 см), це 3 бали за Державними тестами. Також низькі показники бігу на 60 м: юнаки - 9,86 с при розбіжності $(9,6-10,2)$; дівчата - 12,2 с, варіації (10,5-12 c). Нижче 2 балів були також середні показ- ники спритності (човниковий біг 4x9 м) у юнаків 11,6 с при варіаціях $(10,8-12,5$ с $)$ та дівчат - 12,4 с при варіаціях (11,5 - 13,9 с). Силова витривалість м'язів живота (піднімання тулуба з положення лежачи в сід за 1 хвилину) була достовірно кращою у юнаків - 41,8 разів, при варіації (39-42,9 разів), порівняно 3 показниками дівчат - 35,5 раз при варіації (33,5-36 разів). Сила кисті у юнаків - 37,5 кг значно переважала, порівняно з силою кісті у дівчат $-22,4$ кг $(\mathrm{P}<0,01)$. Середні показники станової сили хлопців також були достовірно кращими - 113,8 кг порівняно 3 показниками дівчат -75 кг (P<0,01) (Див. табл. 2).

Таблиця 2

Середні показники фізичних даних школярів 10 класів до педагогічного експерименту

\begin{tabular}{|c|c|c|c|c|c|c|c|c|c|}
\hline \multirow[t]{2}{*}{ Стать } & \multirow[t]{2}{*}{$\mathbf{n}$} & \multirow{2}{*}{$\begin{array}{l}\text { Гнуч - } \\
\text { кість } \\
\text { (см) }\end{array}$} & \multicolumn{2}{|c|}{$\begin{array}{c}\text { Шв.-силові якості } \\
\text { Стрибки }\end{array}$} & \multirow{2}{*}{$\begin{array}{c}\text { Підні- } \\
\text { мання } \\
\text { тулуба } 3 \\
\text { лежачи } \\
\text { в сід (кіл. } \\
\text { разів) }\end{array}$} & \multirow{2}{*}{$\begin{array}{c}\text { Швид- } \\
\text { кість } \\
\text { Біг } 60 \\
\text { м } \\
\text { (c) }\end{array}$} & \multirow{2}{*}{$\begin{array}{l}\text { Сприт- } \\
\text { ність } \\
\text { Човн. } \\
\text { біг } \\
4 \times 9 \text { м } \\
\text { (c) }\end{array}$} & \multicolumn{2}{|c|}{ Сила } \\
\hline & & & $\begin{array}{c}\text { через } \\
\text { скакал. } \\
\text { (кільк. } \\
\text { разів) }\end{array}$ & $\begin{array}{c}\text { у довжи- } \\
\text { ну } 3 \\
\text { місця } \\
\text { (см) }\end{array}$ & & & & $\begin{array}{l}\text { KI- } \\
\text { cri } \\
\text { (Kr) }\end{array}$ & $\begin{array}{l}\text { ста- } \\
\text { но- } \\
\text { ва } \\
\text { (кг) }\end{array}$ \\
\hline Ю & 35 & $\begin{array}{l}9,2 \pm \\
2,3\end{array}$ & $96,5 \pm 4,2$ & $\begin{array}{c}176,6 \pm \\
3,6\end{array}$ & $41,8 \pm 3,7$ & $\begin{array}{c}9,86 \pm \\
0,34\end{array}$ & $\begin{array}{c}11,6 \pm \\
0,2\end{array}$ & $\begin{array}{c}37,5 \pm \\
1,8\end{array}$ & $\begin{array}{l}113,8 \pm \\
3,6\end{array}$ \\
\hline Д & 52 & $\begin{array}{c}12,7 \pm \\
3,1\end{array}$ & $\begin{array}{c}102,2 \pm \\
5,3\end{array}$ & $\begin{array}{c}171,8 \pm \\
5,2\end{array}$ & $35,5 \pm 2,8$ & $\begin{array}{c}11,2 \pm \\
0,4\end{array}$ & $\begin{array}{c}12,4 \pm \\
0,37\end{array}$ & $\begin{array}{c}22,7 \pm \\
2,3\end{array}$ & $\begin{array}{l}75 \pm \\
2,4\end{array}$ \\
\hline
\end{tabular}

Всі школярі 10-х класів після експерименту підвищили показники фізичних даних, але на різну величину (Таблиця 3). Гнучкість юнаків як контрольного, так і експериментальних класів збільшилась 3 низького рівня до задовільного (з 2-х балів до 3-х балів) за Державними тестами: 10-а, К - на 3,8cм, 10-б, Е1 - на $1,8 \mathrm{~cm}, 10-$ в, Е2 - на 3,8cм.

Обговорення результатів дослідження

Середні показники довжини тіла юнаків збіль- шились у контрольному (10-a, К) та в експериментальному (10-б, E1) класах в середньому на 9,5 см, а в експериментальному (10-в, Е2) - на 10,5 см $(\mathrm{P}<0,05)$. Порівняно 3 оціночними таблицями, показники довжини тіла юнаків підвищилися до середнього рівня (від $\mathrm{M}+1 \boldsymbol{\sigma}$ до M-1б). У дівчат за цей період за середніми показниками довжини тіла достовірних змін не визначено як у контрольному, так і в експериментальних класах, хоча окремі дівчата за індивідуальними 
показниками виросли на 2 - 3 см і таких було більше в експериментальних класах. Маса тіла юнаків контрольного 10-а, К класу достовірно не змінилась а у дівчат - збільшилась у середньому на 2,6 кг (вище середніх величин від $\mathrm{M}+1 \boldsymbol{\sigma}$ до $\mathrm{M}+2 \boldsymbol{\sigma}),(\mathrm{P}<0,05)$.

Антропометричні ma фiзіологічні показники иколярів 10 класів піс

\begin{tabular}{|c|c|c|c|c|c|c|c|}
\hline \multirow[t]{3}{*}{ Класи* } & \multirow[t]{3}{*}{ Стать } & \multicolumn{2}{|c|}{ Антропометричні } & \multicolumn{4}{|c|}{ Фізіологічні показники } \\
\hline & & $\begin{array}{c}\text { Довжина } \\
\text { тіла }\end{array}$ & Maca & ЖЕ Л & AT & $\mathrm{SpO}^{2}$ & YCC \\
\hline & & $\mathrm{C}_{\mathrm{M}}$ & $\mathrm{Kr}$ & Л & Mм. pI. ст. & $\%$ & $\mathrm{y}_{\mathrm{A}} / \mathrm{X}_{\mathrm{B}}$ \\
\hline \multirow[t]{2}{*}{$\mathbf{1 0 - \mathbf { a } , \mathbf { K }}$} & Ю & $176 \pm 0,62$ & $64 \pm 2,3$ & $3,4 \pm 0,3$ & $116 / 79 \pm 0,8 / 2$ & $95,3 \pm 0,2$ & $69 \pm 3,1$ \\
\hline & Д & $167 \pm 0,53$ & $58 \pm 3,1$ & $2,7 \pm 0,4$ & $112 / 76 \pm 1,2 / 3$ & $96 \pm 0,1$ & $82 \pm 2,3$ \\
\hline \multirow[t]{2}{*}{$10-6, \mathrm{E} 1$} & Ю & $176 \pm 0,63$ & $62,2 \pm 3,5$ & $3 \pm 0,5$ & $115 / 71 \pm 2,1 / 4$ & $97,5 \pm 0,4$ & $68 \pm 2,1$ \\
\hline & Д & $165 \pm 0,48$ & $57 \pm 2,6$ & $2,6 \pm 0,42$ & $117 / 76 \pm 3 / 0,7$ & $97,5 \pm 0,3$ & $69 \pm 3,2$ \\
\hline \multirow[t]{2}{*}{ 10-в,E 2} & Ю & $177 \pm 0,67$ & $60,9 \pm 4,1$ & $3,4 \pm 0,23$ & $121 / 76 \pm 3 / 0,2$ & $98 \pm 0,4$ & $63 \pm 4,3$ \\
\hline & Д & $166 \pm 0,52$ & $56 \pm 3,5$ & $2,63 \pm 0,24$ & $109 / 72 \pm 4 / 1,4$ & $98 \pm 0,5$ & $70 \pm 2,7$ \\
\hline
\end{tabular}

*10-а,К - контрольний клас; 10-б, Е-1 - ігровий клас; 10-в, Е-2 - експериментальний клас з використанням тренажерів.

В експериментальних 10-б, Е1 класах маса тіла юнаків зменшилась у середньому на 1,7 кг, а в 10-в, Е2 - на 3 кг $(\mathrm{P}<0,05)$. У дівчат в експериментальних класах маса збільшилась: 10-б, Е1 - на 1,6 кг (Р<0,05), а в 10-в, Е2 - на 0,6 кг, але недостовірно (Р>0,05). Життєва ємність легенів за середніми показниками достовірно не змінилась як у контрольному, так і в експериментальних класах як у юнаків, так і в дівчат. Середні показники артеріального тиску збільшились як у контрольному, так і в експериментальних класах, що вказує на продовження формування функціональних адаптаційних резервів у школярів (Йолтухівський та інші, 2017: 32). ЧСС у юнаків контрольного класу зменшилась в середньому на 10,3 уд/хв., в експериментальних: в 10-б, Е1 - ЧСС зменшилась на 11,3 уд/хв., а 10-в, Е2 - на 16,3 уд/хв. $(\mathrm{P}<0,05)$. У дівчат у контрольному класі середні показники ЧСС навіть збільшились на 5,8 уд/хв. ( $<0,05)$, а в контрольних ці показники зменшились в 10-б, E1 - на 7,2 уд/хв., в 10в, Е2 класі - на 6,2 уд/хв. $(\mathrm{P}<0,05)$. Зменшення ЧСС після експерименту вказує на підвищення економічності роботи серцевого м'язу, тобто - на підвищення тренованості школярів експериментальних класів. Середні показники насичення артеріальної крові киснем $\left(\mathrm{SpO}^{2}\right)$ за середніми показниками в юнаків у контрольному класі достовірно не змінились, але мають тенденцію до зниження (на $0,9 \%, \mathrm{P}>0,05$ ), а в експериментальних класах ці показники покращились: в 10-б, Е1 - на 1,3\%, в 10-в, Е2 - на 1,8\% (P<0,05). У дівчат у показниках $\mathrm{SpO}^{2}$ відбулись аналогічні, але більш виражені зміни: в контрольному класі показники достовірно не змінились, а в експериментальних показники покращились: в 10-б, Е1 - на 1,7\%, а в 10 в, Е2 - на 2,2\% $(\mathrm{P}<0,05)$. Такі зміни показують підвищення нормалізації насичення артеріальної крові киснем у старшокласників експериментальних класів після педагогічного експерименту. Змінились майже всі показники фізичних якостей як контрольних, так i експериментальних класів, але на різну величину. Наприклад, дівчата покращили показники гнучкості 3 3-х до 4-х балів: 10-а, К та 10-б, Е1 - на 3,3см, 10-в, Е2 - на 4,3см. Покращились також швидкісно-силові якості школярів, особливо юнаків: стрибки через скакалку, контрольний клас 10 -а, К - на 28,5 раз, 10-б, Е1 та 10 -в, Е2 - на 33,5 раз ( $<<0,01)$, дівчата контрольного класу 10 -а, $\mathrm{K}$ - на 18 раз $(\mathrm{P}<0,05)$, експериментальних: $10-б$, Е1 - на 22,8 рази, 10-в, Е2 - на 27,8 разів $(\mathrm{P}<0,01)$. Значно покращили свої середні показники стрибка в довжину юнаки: контрольного 10 -а, К - на 18,4 см, експериментальних 10-б, Е1 та 10-в, Е2 - на 43,4 см ( $<<0,01)$, і піднялись 31 балу до більше ніж 3 балів за Державними тестами. Дівчата теж покращили свої показники стрибка в довжину з місця але на меншу величину: 10-а, К - на 3,2 см, 10-б, Е1 - на 1,8 см, 10-в, Е2 - на 5,2 см, але за Державними тестами вони залишились на задовільному рівні (3 бали) як і до експерименту.

Показники силової витривалості м'язів живота піднімання тулуба із положення лежачи в сід теж покращились: у юнаків контрольного класу - на 2,2 рази ( $\mathrm{P}>0,05)$ та експериментальних: 10-б,Е1 - на 7,2 рази, в 10 -в, Е2 - на 12,2 рази $(\mathrm{P}<0,05)$. У дівчат середні показники силової витривалості теж покращились, але різниця як до експерименту та між класами після експерименту була недостовірною: в контрольному класі - на 3,5 рази, в ігровому класі - не змінились, у 10-в, Е2 класі 3 пляшковими тренажерами - на 4,5 рази, (Р>0,05). Середні показники швидкості (бігу на 60 м) теж покращились, хоча вони і до експерименту були на високому рівні за Державними тестами: у юнаків контрольного класу - на $0,36 \mathrm{c}(\mathrm{P}>0,05)$; в експериментальних - 10-б, Е1 - на 0,51с; в 10-в, Е2 - на $0,4 \mathrm{c}(\mathrm{P}<0,05)$. 
Таблиця 4

Фізичні дані иколярів 10 класу після експерименту

\begin{tabular}{|c|c|c|c|c|c|c|c|c|c|}
\hline \multirow[t]{2}{*}{$\begin{array}{l}\text { Кла- } \\
\text { си* }^{*}\end{array}$} & \multirow[t]{2}{*}{ Стать } & \multirow{2}{*}{$\begin{array}{l}\text { Гнуч- } \\
\text { кість } \\
\text { (см) }\end{array}$} & \multicolumn{2}{|c|}{$\begin{array}{c}\text { Шв.-силові якості: } \\
\text { стрибки }\end{array}$} & \multirow{2}{*}{$\begin{array}{c}\text { Підні- } \\
\text { мання } \\
\text { тулуба з } \\
\text { лежа- } \\
\text { чи } \\
\text { в сід } \\
\text { (кільк. } \\
\text { разів) }\end{array}$} & \multirow{2}{*}{$\begin{array}{c}\text { Швид- } \\
\text { кість } \\
\text { Біг } 60 \text { м } \\
\text { (c) }\end{array}$} & \multirow{2}{*}{$\begin{array}{c}\text { Сприт- } \\
\text { ність } \\
\text { Човн. } \\
\text { біг } \\
4 \times 9 \mathrm{M} \\
\text { (c) }\end{array}$} & \multicolumn{2}{|c|}{ Сила } \\
\hline & & & $\begin{array}{c}\text { через } \\
\text { скакал. } \\
\text { (кільк. } \\
\text { разів) }\end{array}$ & $\begin{array}{c}\text { у дов- } \\
\text { жи- ну з } \\
\text { місця } \\
\text { (см) }\end{array}$ & & & & $\begin{array}{l}\text { ки- } \\
\text { сті } \\
\text { (кг) }\end{array}$ & $\begin{array}{c}\text { ста- } \\
\text { но- } \\
\text { ва } \\
\text { (кг) }\end{array}$ \\
\hline \multirow[t]{2}{*}{$\begin{array}{c}10-\mathrm{a}, \\
\mathrm{K}\end{array}$} & Ю & $11 \pm 2,3$ & $125 \pm 3.2$ & $195 \pm 4$ & $44 \pm 3$ & $9,5 \pm 0,5$ & $10,4 \pm 0,2$ & $\begin{array}{l}37 \pm \\
3,2\end{array}$ & $\begin{array}{c}112 \pm \\
2.2\end{array}$ \\
\hline & Д & $16 \pm 4,3$ & $130 \pm 4,3$ & $175 \pm 6$ & $39 \pm 4$ & $11 \pm 0,4$ & $10,5 \pm 0,6$ & $\begin{array}{l}23 \pm \\
2,2\end{array}$ & $\begin{array}{l}50 \pm \\
2,6\end{array}$ \\
\hline \multirow[t]{2}{*}{$\begin{array}{c}10-6, \\
\text { E } 1\end{array}$} & Ю & $13 \pm 1,6$ & $130 \pm 5,3$ & $220 \pm 5$ & $49 \pm 6$ & $9,35 \pm 0,5$ & $10,5 \pm 0,3$ & $\begin{array}{r}42 \pm \\
3,4\end{array}$ & $\begin{array}{c}107 \pm \\
3,4\end{array}$ \\
\hline & Д & $16 \pm 3,7$ & $125 \pm 4,2$ & $170 \pm 4$ & $35 \pm 5$ & $10,7 \pm 0,4$ & $12,6 \pm 0,4$ & $\begin{array}{r}22 \pm \\
4,3\end{array}$ & $\begin{array}{r}83 \pm \\
3,6\end{array}$ \\
\hline \multirow[t]{2}{*}{$\begin{array}{c}10-\mathrm{B}, \\
\text { E } 2\end{array}$} & Ю & $13 \pm 2.3$ & $130 \pm 3,6$ & $220 \pm 7$ & $54 \pm 6$ & $9,46 \pm 0,6$ & $10,6 \pm 0,5$ & $\begin{array}{l}50 \pm \\
2,7\end{array}$ & $\begin{array}{c}140 \pm \\
2,7\end{array}$ \\
\hline & Д & $17 \pm 4,3$ & $130 \pm 2,8$ & $177 \pm 6$ & $40 \pm 5$ & $11 \pm 0,3$ & $11,7 \pm 0,7$ & $\begin{array}{r}26 \pm \\
5,4\end{array}$ & $\begin{array}{l}95 \pm \\
4,5\end{array}$ \\
\hline
\end{tabular}

*10-а, К - контрольний клас; 10-б, Е-1 - ігровий клас; 10-в, Е-2 - експериментальний клас з використанням тренажерів.

У дівчат швидкість покращилась: у контрольному класі - на 0,2c (P>0,05); в експериментальних: в 10-б, Е1 - на 0,5с $(\mathrm{P}<0,05)$; в 10-в, Е2 - на 0,2c $(\mathrm{P}>0,05)$. Показники спритності контрольних класах виявились кращими порівняно з експериментальними, хоча у всіх вони покращились порівняно з вихідними даними: у юнаків контрольного класу - на 1,2c; в ігровому класі - на 1,1 ; в класі $з$ тренажерами - на 1с $(\mathrm{P}<0,05) ; \quad$ д дівчат контрольного класу спритність покращилась на 1,3c, а в експериментальних: в ігровому - на 0,4c; 3 пляшковими тренажерами - на 0,9c $(\mathrm{P}<0,05)$; Показники сили кисті виявились кращими в експериментальних класах з використанням тренажерів «Ударник». У юнаків контрольного класу середні показники сили кисті достовірно не змінились, а в експериментальних покращились: в 10-б, Е1 - на 4,5кг; в 10-в, Е2 - на 12,5 кг (P<0,05). У дівчат показники сили кисті не змінились у контрольному класі та в ігровому, а в експериментальному класі 3 тренажерами «Ударник» вони підвищились - на 4,1кг $(\mathrm{P}<0,05)$. Середні показники станової сили після експерименту знизились у юнаків контрольного класу на 2,1кг та ігрового класу - на 6,8кг (Р<0,05); в експериментальному класі 3 тренажерами «Ударник» ста- нова сила у юнаків підвищилась на 26,2кг ( $<00,01)$. У дівчат станова сила знизилась, за середніми показниками, тільки в контрольному класі - на 25кг ( $<<0,01)$; у ігровому класі вона підвищилась на 8кг, а в класі 3 використанням тренажерів «Ударник» станова сила підвищилась в середньому на 20 кг $(\mathrm{P}<0,01)$.

\section{Висновки}

1. Використання тренажерів ударно-хвильової дії «Ударник» на уроках фізичної культури підвищує інтерес старшокласників до фізичної культури.

2. Вправи ударно-хвильової дії за допомогою тренажерів «Ударник» стимулюють зниження маси тіла, підвищують функціональні адаптивні можливості серцево-судинної системи, нормалізують насичення артеріальної крові киснем, добре тренують гнучкість, швидкість, силову витривалість, швидкісно-силові та силові якості школярів.

3. Зважаючи на позитивні показники впливу реверсивної дії ударно-хвильових тренажерів «Ударник» на школярів, і можливість самостійного їх виготовлення, можна рекомендувати такі тренажери для профілактики гіпокінезії та гіподинамії школярів, особливо, в періоди змушеного обмеження рухової діяльності (пандемія, карантин, самоізоляція та інше). 


\section{Література}

1. Агашин М. Ф. Биомеханический резонанс и возможности его использования в медицине. Казанский медиичнский журнал. 1975. T.L VI, №2. С. 22-26.

2. Агашин Ф. К. Биомеханический тренажер Агашина. Москва. 2006. 30 с.

3. Гербут К. В., Хоменко В. Г. Оцінка фізичного стану старшокласників міста Чернівці. "Young Scientist». 2015. April. (№ 4 (19)). Part 3. C. 67-71.

4. Гогулан М. Попрощайтесь с болезнями. Советский спорт. Москва, 2002. 300 с.

5. Йолтухівський М. В., Лойко Л. С., та ін. Дослідження адаптаційних можливостей серцевосудинної системи у старшокласників-кіберадиктів. Вісник наукових досліджень. 2017. № 4. С. 30-32.

6. Носко М. О., Срмаков С. С., Гаркуша С. В. Теоретико-методичні зміцнення фізичного здоров'я учнівської та студентської молоді. Вісник Чернігівського державного педагогічного університету. 2010. № 76. C. 243-247.

7. Петров Г. С., Солодка О. В. Тренажери в фізичній культурі і спорті. Методичні рекомендації для студентів IV курсу денної та заочної форми навчання. Дніпропетровськ, 2010. 39 с.

8. Система здоровья Кацудзо Ниши. СанктПетербург : ИК «Невский проспект», 2004. 320 с .

9. Филатов А. Т. Аутогенная тренировка. Киев: Здоровье, 1987. $128 \mathrm{c.}$

10. Фролов К. В., Миркин А. С., Машанский В. Ф. и др. Вибрационная биомеханика. Использование вибрации в биологии и медицине. Москва: Наука, 1989. $142 \mathrm{c}$.

11. Чустрак А. П. Статокінетична стійкість школярів : монографія (присвячена 200-річчю Університету Ушинського). Одеса: ПНПУ ім. К.Д. Ушинського, 2015. $126 \mathrm{c}$.

12. Чустрак А. П., Кизирян А. Г., Шавриева Т. И. Оздоровление людей среднего и старшего возраста с применением упражнений ударно-волнового воздействия: матеріали XII міжнародної наук.-прак. конф., м. Одеса, 13-14 верес. 2018 р. Ч. 2. Одеса, 2018. C. $101-105$

13. Laputin A. N., Utkin V.L. Technical means of training: Manual for institutes of physical education. Moscow: Physical education and sport, 1990. 80 p.

14. Lubysheva L. I. Sociology of physical education and sport: study guide. Moscow: Publishing center "Academy", 2001. 240 p.

15. Topchiieva H. O. Use of exercises for everyone". Vol. 2. Almaty, 2004. P. 54-55. On training equipment in the course of physical education of students. Physical education in the context of modern education : materials of VII All-Ukrainian scientific and methodical conference. Kyiv : NAU, 2012. P. 150-153.

16. Watson J. Training equipment. Moscow: Svit, 2001. 27 p.

\section{References}

1. Agashin, M. F. (1975). Biomekhanicheskiy rezonans i vozmozhnosti ego ispolzovaniya $\mathrm{v}$ meditsine. Kazanskiy meditsinskiy Zhurnal. [Biomechanical resonance and the possibilities of its use in medicine]. Kazan Medical Journal. T.L VI, 2, 22-26 [in Russian].

2. Agashin, F. K. (2006). Biomekhanicheskiy trenazhor Agashina [Biomechanical Agashin simulator]. Moscow [in Russian].

3. Herbut, K. V. \& Khomenko, V. G. (2015). Otsinka fizychnogo stanu starshoklasnykiv mista Chernivtsi [Assessment of physical state of high school students of Chernivtsi city]. "Young Scientist», 4 (19). Part 3, (pp. 67-71) [in Ukrainian].

4. Gogulan, M. (2002). Poproshchaytes $s$ boleznyami [Say goodbye to disease]. Moscow: Soviet sport [in Russian].

5. Yoltukhivsky, M. V., Loiko L. S., Sasovets, A. O., Tysevych, T. V., Rysynets, T. P. \& Karlashchuk, R. V. (2017). Doslidzhennia adaptatsiynykh mozhlyvostei sertsevo-sudynnoi systemi u starshoklasnykivkiberadyktiv [Investigation of cardiovascular adaptive capacity in high school cyberadapters]. Bulletin of scientific research, 4, 30-32 [in Ukrainian].

6. Nosko, M. O., Yermakov, S. S. \& Garkusha, S. V. (2010). Teoretyko-metodychni zmitsnennia fizychnogo zdorovia uchnivskoi ta studentskoi molodi [Theoretical and methodological strengthening of physical health of pupils and students]. Bulletin of Chernigiv national ped. un-ty named after T. G. Shevchenka. Vol. 76, (pp. 243247). Chernigiv [in Ukrainian].

7. Petrov, G. S., Solodka, O. V. (2010). Trenazheri v fizychnii kulturi i sporti. Metodychni rekomendatsii dlia studentiv IV kursu dennoi ta zaochnoi formy navchannia [Exercise machines in physical culture and sports. Methodical recommendations for full-time and part-time fourth-year students teaching]. Dnipropetrovsk [in Ukrainian].

8. Katsudzo, Nishi. (2004). Sistema zdorovia [The Health System of Katsudzo Nishi]. St. Petersburg: IC «Nevsky Prospect» [in Russian].

9. Filatov, A. T. (1987). Autogennaia trenirovka [Autogenic training]. Kiev: Health [in Russian].

10. Frolov, K. V., Mirkin, A. S., Mashansky, V. F., et al. (1989). Vibratsionnaya biomekhanika. Ispolzovaniye vibratsii $v$ biologii $i$ meditsine [Vibration biomechanics. The use of vibration in biology and medicine]. Moscow: Science [in Russian].

11. Chustrak, A. P. (2015). Statokinetychna stiikist shkoliariv [Statokinetic stability of schoolchildren] [in Ukrainian].

12. Chustrak, A. P., Kizirian, A. G., Shavriieva, T. I. (2018). Ozdorovleniie liudey srednego i starshego vozrasta $\mathrm{s}$ primeneniiem uprazhneniy udarno-volnovogo vozdeystviya [Health improvement of people of middle and older age with the use of shock-wave exercises]. Proceedings from XII International Science and Practical Conference of 13-14 September, Odessa, part 2, 101-105 [in Russian].

13. Laputin, A. N. \& Utkin, V. L. (1990). Technical means of training: Manual for institutes of physical education. Moscow: Physical education and sport [in English].

14. Lubysheva, L. I. (2001). Sociology of physical education and sport: study guide. M: Publishing centre "Academy" [in English]. 
15. Topchiieva, H. O. (2012). Use of exercises for everyone. Vol. 2. Almaty, 2004. (pp. 54 - 55). On training equipment in the course of physical education of students. Physical education in the context of modern educa- tion. Proceedings from VII All-Ukrainian scientific and methodical conference, 150-153. Kiev: NAU [in English]. 16. Watson, J. (2001) Training equipment. Moscow: Svit [in English].

\author{
Anatoliy Chustrak, \\ PhD (Candidate of Pedagogical Sciences), \\ associate professor, privat-professor, \\ Department of Gymnastics and Martial Arts, \\ Artemiy Kizirian, \\ high achiever of education of Ukraine, \\ Edward Kizirian, \\ a first-year student, \\ Medical Department, \\ The State institution "South Ukrainian National Pedagogical University \\ named after K. D. Ushynsky", \\ 26, Staroportofrankivska, Odessa, Ukraine
}

\title{
INFLUENTIAL FEATURES OF REVERSE ACTION OF SHOCKWAVE SIMULATORS ON PHYSIOLOGICAL AND PHYSICAL STATES OF STUDENTS
}

The empirical studies of reverse action of shockwave simulators on physical state of high school students (n-85) were organized in comparison with other physical means in order to heighten the interest of high school students in physical education and increase their physical activity. The studies were conducted in three classes in physical education lessons in the preparatory part, three times a week for 15 minutes, for six months. The first class was the control, the second one includes sports games, and the third - general development exercises with simulator «Udarnik». At the beginning and at the end of the experiment, 2 anthropometric indicators, 4 physiological indicators and 8 indicators of physical abilities were determined in high school students and how these indicators are affected by shockwave simulators in comparison with other means of physical training in six months. Almost all the physical qualities of high school students were low before the pedagogical experiment. After a six-month experiment, almost all indicators of students of experimental classes were significantly improved. According to state standarts, they have shown good and satisfactory results in both physical development and basic physical qualities with the exception of agility. The using of shockwave simulators «Udarnik» in physical education lessons heighten the interest of students in physical education. Such exercises reduce body weight, increase the functional adaptive capabilities of the cardiovascular system. They can also improve flexibility, speed, endurance, speed and power and also strength qualities of students. The results of the study can be useful for coaches and physical education teachers in primary and secondary general school.

Keywords: high school students, shockwave simulators, exercises of shockwave action, physical qualities, physical preparation. 